\title{
Organizational competitiveness factors
}

\author{
Darlan José Roman ${ }^{\dagger}$ \\ Santa Catarina Federal University \\ $\Omega$ \\ Janaina Piana \\ Santa Catarina Federal University \\ Marie-Anne Stival Pereira e Leal Lozano \\ Santa Catarina Federal University \\ Nelson Ruben de Mello $\ddagger$ \\ Pampa Federal University (UNIPAMPA)

\section{Rolf Hermann Erdmann $\Theta$} \\ Santa Catarina Federal University
}

\begin{abstract}
The objective of this article is to identify in the business administration literature the elements considered most important to improve business performance, based on content analysis of academic articles on subjects related to competitiveness, productivity, efficiency and performance. The data come from periodicals available from sources listed at the CAPES portal in the period from 2000 to 2009. From the analysis of 486 articles, we identified 15 organizational competitiveness factors: strategic alliances, human capital, reliability, knowledge, cost, cultural factors, flexibility, innovation, quality, speed, customer relations, social responsibility, control systems, production techniques, and information and communication technologies. These factors have the potential to contribute to the establishment of organizational priorities and can be considered as guides for the construction of management instruments and the implementation of actions to improve competitiveness.
\end{abstract}

Keywords: Competitiveness factors; business organizations.

Received on 07/15/2010; reviewed on 10/01/2010; accepted on 12/16/2010; avaialable in 03/05/2012

Corresponding author*:

\begin{tabular}{|c|c|c|}
\hline${ }^{t} \mathrm{PhD}$ Studente in & ${ }^{\Omega}$ Master in Business & ${ }^{¥}$ Master in Business \\
\hline Administration by & Administration at the & Administration at the \\
\hline Federal University of & Federal University of & Federal University of \\
\hline Santa Catarina & Santa Catarina. & Santa Catarina. \\
\hline Address: Rua João & Address: Rua & Address: Rua Servidão \\
\hline Marçal, 120, apto 31. & Professora Maria do & Natureza, 463. Bairro \\
\hline Bairro Trindade. & Patrocínio Coelho, no. & Campeche. \\
\hline Florianópolis - SC & 49 , apto 6 & Florianópolis - \\
\hline - Brazil. & Florianópolis $-\mathrm{SC}-$ & SC - Brazil. \\
\hline CEP: 88036-620 & Brazil. & CEP: $88053-545$ \\
\hline E-mail: & CEP: $88040-230$ & Email: marie.leallozan \\
\hline darlanroman@yaho & E-mail: & o@gmail.com. \\
\hline m.br & janainapiana@hotmail. & Telefone: (48 ) 9149- \\
\hline Telephone & com Telefone: (48 & 3239 / 3206-3229 \\
\hline 96087668 & )84248602 & \\
\hline
\end{tabular}

PhD in Production
Engineering from
Universidade Federal
de Santa Catarina
Adjunct Professor,
Federal University of
Pampa (UNIPAMPA)
Address: Av. Barão do
Upacarai, 969 . Dom
Pedrito - RS - Brazil
CEP: $96450-000$
E-mail:
ndemello49@ hotmail.c
om. Telefone: (53)
99740260
(48) 96166420

(48)96166420
$\Theta \mathrm{PhD}$ in Production Engineering from Universidade Federal de Santa Catarina Associate Professor, Federal University of

Santa Catarina.

Address: Rua Frei

Caneca, no. 100, 1001-

A, Florianópolis - SC

- Brazil

CEP 88025-000

E-mail:

erdmann@newsite.com

.br; Telefone: 048-

32288312 Fax: 048-

37219539

Nota do Editor: Esse artigo foi aceito por Antonio Lopo Martinez.

\section{(cc) BY-NC-SA}

Esta obra está licenciada sob a Licença Creative Commons - Atribuição-Uso não-comercial-Compartilhamento pela mesma licença 3.0 Unported License 


\section{INTRODUCTION}

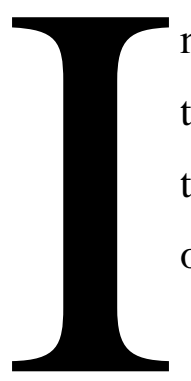

$\mathrm{n}$ the modern business world, a firm's capacity to compete depends on its ability to change and develop new strategic directions. The process of thinking about the new, of considering novel ideas and solutions, plays a crucial role in terms of acquiring a competitive edge.

To help in this task, it is important to search the business administration literature for characteristics or aspects considered key to the generation of competitiveness. The priorities to achieve competitive advantages can be defined as a consistent set of performance characteristics that can contribute to enhance a firm's competitiveness (Castro, Santos \& Silva 2008).

A competitiveness factor can be viewed as configuring a real concern and reason for being of the firm. These "basic reasons" or "reasons for being" are aspects that, upon being clearly identified, can help improve the organization, or more specifically, enhance its performance. It can be said that the competitiveness factor corresponds to the variables in which the organization needs to perform well to survive and stand out in the market.

The study of the elements that generate competitiveness is important for firms to find the best way to develop products and processes, with the use of the best practices in terms of costs and quality, to serve consumers' needs best. Observation of the competitiveness factors is essential for a firm to improve its performance and thus realize its mission, strategic objectives and vision of the future.

The aim of this article is to highlight from the recent academic production the factors that are considered in the search for competitiveness. It is based on consultation of scientific articles on administration available form the sources listed at the portal of CAPES (the office of the Brazilian Ministry of Education charged with improving graduate education and research) addressing themes related to competitiveness, productivity, efficiency and performance.

\section{METHODOLOGY}

Our methodological strategy was based on analysis by category, the most often used form of content analysis. Content analysis can be defined as a set of data analysis techniques that aim to obtain, by means of systematic procedures, quantitative or 
qualitative indicators of the semantic or syntactic properties of the matter under study (Bardin, 2004; Richardson et al., 1999).

For this study, we applied categorization techniques to the academic articles available in the main databases in the business administration area of the CAPES Portal, namely: Scielo, Gale, Wilson, Sage, ScienceDirect and Ebsco. We decided not to initially rank the publications (based on criteria of academic qualification, as is done by QUALISCAPES), to avoid biasing the sample in function of determined theoretical orientations or dominant groups in the literature in terms of academic output (Russo, Macedo-Soares \& Villas, 2006). We therefore sought an ample criterion for mapping viewpoints, to permit extracting from the specialized literature the various perspectives that exist regarding the determining factors of organizational performance.

The selection of empirical material in the pre-analysis phase consisted of searching for articles in the above databases by means of the keywords competitiveness, productivity, efficiency, effectiveness and performance, for the period from 2000 to 2009. In the search process, we used these keywords with the aid of a filter mechanism, so that the selection was limited to articles in which these words are present in one or more of the following fields: title, summary/abstract and keywords. By this search strategy we identified 486 scientific articles.

We then carried out the content analysis itself, by means of a categorization process in function of a semantic criterion. This procedure consisted of first formulating an inventory of the terms identified as factors able to influence organizational performance, by means of reading the abstract, and possibly the entire article. In this step we discarded the articles that did not clearly establish a connection between one or more of these factors and organizational competitiveness. This led to the selection of 198 expressions indicated in the texts as competitiveness factors.

In the next step, by means of content analysis we followed a procedure for grouping the expressions in function of the progressive classification of their elements, meeting the requirements of comprehensiveness (inclusion of all elements considered) and exclusivity (no element was classified in two categories). Satisfaction of these requirements is inherent to categorization techniques. Therefore, we grouped the expressions according to similarities in the messages on competitiveness expressed, that is, so as to indicate a single conceptual logic. For example, when an article presented clean technologies as a competitiveness factor, we considered the logic behind this action to be social responsibility. Likewise, when an article presented as a factor the development of new 
products, new initiatives or new business endeavors, we categorized the logic as falling under innovation. In this way, we analyzed all the competitiveness expressions identified in the previous step, and could note that some of them were governed by the same conceptual logic, that is, based on the same value. This allowed selecting the predominant factors.

The option to identify the factors through a recursive process instead of employing previously defined categories based on theoretical references implied the need for a final step for theoretical justification of the relevance and pertinence of the categories constructed. As a result, we configured 15 groups of competitiveness factors, represented in Figures 2 to 16 of Section 5.

\section{COMPETITIVENESS IN BUSINESS ORGANIZATIONS}

Meeting the expectations of firms, dictated mainly by the search for consistent profits by satisfactorily resolving the inherent business uncertainties, in the final analysis rests on being competitive. Achieving this requires more than expectation, however, it requires firms to develop capabilities to turn expectations into reality (Lemos \& Nascimento, 1999).

These capabilities are associated with factors that can be classified into areas or that express abilities, with positive developments in the market, on production and on finance. They relate to the firm's people, methods, planning capacity, organization and control, at levels able to meet the challenges of rival firms, to compete. The ability to compete means staying alive in the market.

One of the first references to the expression "competitive advantage" in the strategy literature can be found in Ansoff (1965, pp. 188-194), who defined it as the advantage of proactively anticipating market trends better than competitors and adjusting supply in function of this perception. This interpretation has a marketing connotation, and hence is only partial. It is necessary to consider that the ability to compete can be the fruit of different competencies, which can be based on different functional areas, administrative functions or categories of specialization.

Competitiveness is evidently a decisive factor for survival in the business world. To achieve it requires setting priorities, which can be defined as a set of options of varying importance that a firm needs to have to compete in the market over a determined time frame (Santos, Pires \& Gonçalves, 1999). Further according to these authors, this concept came to be perceived as particularly relevant in manufacturing after the work of Skinner 
(1969), who pointed out common patterns to measure production performance. Skinner (1969) indicated the following characteristics: reduce product delivery cycles, have highquality and reliable products, honor delivery schedules, have flexibility to adjust to volume changes and achieve low costs.

Slack et al. (1997) define five factors that contribute to firms' competitive advantage: (1) dependability; (2) cost; (3) flexibility, (4) quality; and (5) speed. According to these authors, by attaining these five objectives, the organization will solidify its superiority in the market.

According to Davis (2001), besides costs, quality and flexibility, fast delivery and good service are competitive priorities. Delivery is related to the speed factor of Slack et al. (1997), because it entails supplying products quickly, while service involves the way products are delivered and accompanied after sales. He also points to another priority, consisting of offering products that do not harm the environment and that are produced by processes with the same characteristic.

A combined analysis of various authors in the business administration area shows an emphasis on the following factors that determine competitiveness: quality, cost, flexibility and reliability, or dependability (Scopinho, 2000; Buiar, 1999; Stevenson, 2001; Buffa, 1972). Porter (2001) believes that strategies for success wind up determining a set of premises that cannot be replaced unless they no longer add value to the organization. For an organization to become highly competitive, it is necessary to identify the factors that influence its competitiveness.

In this line, Machado-da-Silva \& Barbosa (2002) believe that implementing successful knowledge management creates a flexible competitive advantage that is hard do imitate, because it goes beyond the limits of physical resources, which are rigid and easy to imitate, and extends to an exclusive aspect of the organization that it difficult for others to appropriate. Therefore, the firm acquires a competitive advantage by means of the relationship of knowledge with the ability to innovate and to configure a flexible structure capable of reacting favorably to the frequent changes in its environment.

The study of competitiveness factors is important to achieve the most suitable method for developing products and processes, with the use of the best practices and at the lowest possible costs, to make high quality products and get them to market quickly so as to satisfy consumers' needs. Mastery of the critical factors is indispensable for an organization to perform better and thus meet its goals. 
Bandeira (2007) believes that the critical success factors are elements that permit the firm to reach the best possible levels of competitiveness and as such are of great importance to control objectives. As he puts it:

Critical success factors correspond to the variables in which the organization needs to perform well to be competitive. The critical factors for success sustain the management indicators to be measured and monitored. Analysis of the data by means of time series permits prospection of forecasting models for the performance indicators (Bandeira, 2007: 4).

According to Silva (2002: 19), "the logic on which organizational actions are based can be found in the message expressed by the competitiveness factors." A company can valorize a perceived criterion as a generator or competitiveness in detriment to another, according to its specific conditions of operation.

Starting from the notion of critical factors for competitiveness, it is possible to note the close relationship they have with a firm's success. Knowledge of the competitiveness factors will allow the organization to work in harmony with the demands of its environment, structure itself correctly, reduce uncertainties and perform better.

\section{RESULTS AND ANALYSIS OF THE DATA}

The aim of this study was to identify competitiveness factors for development of organizational strategies. As stated, it was possible to find 15 groups of organizational competitiveness factors: strategic alliances, human capital, reliability, knowledge, cost, cultural factors, flexibility, innovation, quality, speed, customer relations, social responsibility, control systems, production techniques and information and communication technologies. These categories are summarized in the charts below.

\begin{tabular}{|c|c|c|c|}
\hline FACTOR & $\begin{array}{l}\text { EXPRESSION } \\
\text { FOUND }\end{array}$ & JUSTIFICATION & REFERENCE \\
\hline \multirow{3}{*}{ 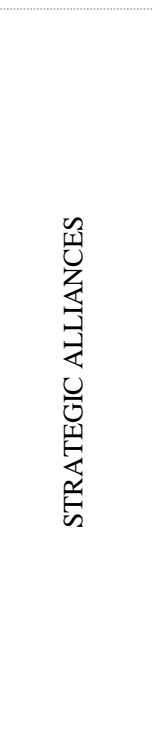 } & $\begin{array}{l}\text { Supply Chain } \\
\text { Integration }\end{array}$ & $\begin{array}{l}\text { Supply chain integration has become one of the } \\
\text { best paradigms to create competitiveness over the } \\
\text { long run. }\end{array}$ & $\begin{array}{l}\text { Cook, Jack; Ajmera, Abhinav. A } \\
\text { Multi-Phase Framework for Supply } \\
\text { Chain Integration. SAM Advanced } \\
\text { Management Journal. 2009. [S.I]. }\end{array}$ \\
\hline & $\begin{array}{l}\text { Cooperative } \\
\text { Norms }\end{array}$ & $\begin{array}{l}\text { Cooperative norms can positively affect customer } \\
\text { satisfaction. By means of cooperative norms, } \\
\text { partners cooperate to reach common objectives } \\
\text { (Siguaw, Simson \& Baker, 1998). That } \\
\text { cooperative relationship lowers transaction costs } \\
\text { and enables resolving disputes amicably, as well } \\
\text { as helping face other contingencies inherent to } \\
\text { the particular business (Claro, Hagelaar \& Omta, } \\
\text { 2003). Moreover, cooperative norms can prevent } \\
\text { opportunistic behavior in a relationship. }\end{array}$ & $\begin{array}{l}\text { Cai, Shaohan; Yang, Zhilin. } \\
\text { Development of Cooperative Norms } \\
\text { in the Buyer-Supplier Relationship: } \\
\text { The Chinese Experience. Journal of } \\
\text { Supply Chain Management, v.44, pp. } \\
55-70, \text { n. 1, Feb. 2008, }\end{array}$ \\
\hline & $\begin{array}{l}\text { Supply Chain } \\
\text { Management }\end{array}$ & $\begin{array}{l}\text { Supply chain management has become a way to } \\
\text { improve competitiveness, by reducing } \\
\text { uncertainties and improving customer service. }\end{array}$ & $\begin{array}{l}\text { Chandra, Charu; Kumar, Sameer. } \\
\text { Supply Chain Management in Theory } \\
\text { and Practice: A Passing Fad or a } \\
\text { Fundamental Change? Industrial } \\
\text { Management \& Data Systems, v. 100, } \\
\text { n. 3, pp. 100-114, 2000. }\end{array}$ \\
\hline
\end{tabular}

Chart 1: Examples of factors related to strategic alliances.

Source: Prepared by the authors. 
The formation of strategic alliances is based on organizational principles that seek to articulate relationships between competing firms, distributors and suppliers of raw materials and other inputs, aiming to distribute risks and increase the ability to compete. The expressions found in the literature related to competitive alliances were: strong integrated supply chain, alliances, business alliances, strategic alliances, value chain, supply chain integration, combined business and marketing strategy, geographic concentration of firms, exclusive suppliers, mergers and acquisition, sustainable supply chain management, corporate governance, logistics, industrial respect and support, cooperative norms, regional commercial pacts, supply chain management and holistic vision of managing partnerships.

\begin{tabular}{|c|c|c|c|}
\hline FACTOR & EXPRESSION FOUND & JUSTIFICATION & REFERENCE \\
\hline \multirow{3}{*}{ 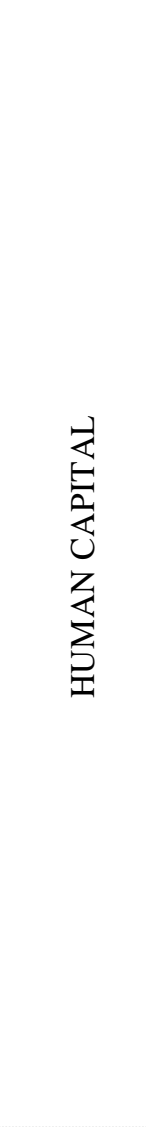 } & $\begin{array}{c}\text { Management of } \\
\text { Talents }\end{array}$ & $\begin{array}{l}\text { Many studies have shown that } \\
\text { executives consider management of } \\
\text { talents as the main differentiation } \\
\text { factor between companies, making it } \\
\text { an important strategic priority. }\end{array}$ & $\begin{array}{l}\text { Kontoghiorghes, Constantine; } \\
\text { Frangou, Kalomyra. The } \\
\text { Association between Talent } \\
\text { Retention, Antecedent Factors, } \\
\text { and Consequent Organizational } \\
\text { Performance. SAM Advanced } \\
\text { Management Journal, Jan. 2009, } \\
\text { [S.I]. }\end{array}$ \\
\hline & $\begin{array}{l}\text { Investment and } \\
\text { Development } \\
\text { of } \\
\text { Competencies }\end{array}$ & $\begin{array}{l}\text { Investment and development of } \\
\text { competencies are positively and } \\
\text { significantly correlated } \\
\text { competitiveness. }\end{array}$ & $\begin{array}{l}\text { Singh, Rajesh K.; Garg, Suresh } \\
\text { K.; Deshmukh, S.G. Strategy } \\
\text { Development } \\
\text { Competitiveness: A Study on } \\
\text { Indian Auto Component Sector. } \\
\text { International Journal of } \\
\text { Productivity and Performance } \\
\text { Management, v. 56, n. 4, pp. } \\
\text { 285-304, 2007. }\end{array}$ \\
\hline & Selection of Personnel & $\begin{array}{l}\text { Some firms have ignored the potential } \\
\text { contribution that the procedures of a } \\
\text { good hiring process can have on the } \\
\text { firm's performance, relying more on } \\
\text { efforts to improve work and motivate } \\
\text { and develop workers after hiring as a } \\
\text { way to boost performance. But the } \\
\text { most significant impact on productivity } \\
\text { can be tied to the process of selecting } \\
\text { new employees, so as to hire the best } \\
\text { people available. }\end{array}$ & $\begin{array}{l}\text { Terpstra, David E. HRM: A Key } \\
\text { to Competitiveness. } \\
\text { Management Decision, v. 32, n. } \\
\text { 9, pp. 10-14, 1994. }\end{array}$ \\
\hline
\end{tabular}

Chart 2: Examples of factors related to human capital.

Source: Prepared by the authors.

The human capital factor includes the following terms found in the literature research: organizational learning, human capital, competencies, ethical behavior, development of competencies, development and refreshment of technical skills, development of personnel, development of human resources, education and training, lifetime employment, specialization of labor, ethics, human resources management, 
management of talents, technical and management skills, harmonious labor relations, ongoing investment to develop human capital, planning for leadership and succession, learning programs, quality of life at work, occupational health, selection of persons, welltrained and motivated workers, training, workers with confidence and leadership, and teamwork. The presence of these human capital elements means an organization is more likely to be competitive, by means of training, workforce integration and motivation, among other factors.

\begin{tabular}{|c|c|c|c|}
\hline FACTOR & $\begin{array}{l}\text { EXPRESSION } \\
\text { FOUND }\end{array}$ & JUSTIFICATION & REFERENCE \\
\hline \multirow{3}{*}{ 党 } & $\begin{array}{l}\text { Conformance and } \\
\text { Reliable Delivery }\end{array}$ & $\begin{array}{l}\text { There is a hierarchy of competitive } \\
\text { capabilities [...] that are more likely to impact } \\
\text { perceived product quality. These are, in their } \\
\text { order of importance: conformance, delivery } \\
\text { reliability, delivery speed, customer relations, } \\
\text { speed of product development, and } \\
\text { introduction and finally low cost. }\end{array}$ & $\begin{array}{l}\text { Ehie, Ike C.; Stough, Stanley. Cycle } \\
\text { Time Reduction through Various } \\
\text { Business Subcycles. Industrial } \\
\text { Management, May 1995, [S.I]. }\end{array}$ \\
\hline & $\begin{array}{c}\text { Quality } \\
\text { Measurements }\end{array}$ & $\begin{array}{l}\text { The results revealed four items for } \\
\text { construction of long-lived firms: customer } \\
\text { focus, total quality management (TQM), } \\
\text { process quality and quality measurements. }\end{array}$ & $\begin{array}{l}\text { Mady, M. Tawfik. Quality } \\
\text { Management Practices: An } \\
\text { Empirical Investigation of } \\
\text { Associated Constructs in Two } \\
\text { Kuwaiti Industries. International } \\
\text { Journal of Quality \& Reliability } \\
\text { Management, v. 26, n. 3, pp. 214- } \\
\text { 233, 2009. }\end{array}$ \\
\hline & $\begin{array}{l}\text { Total Reliability } \\
\text { Management }\end{array}$ & $\begin{array}{l}\text { The quality performance of a firm is often } \\
\text { assessed by the reliability of its equipment or } \\
\text { machinery. Yet reliability has not received the } \\
\text { same attention as quality. Several } \\
\text { organizations today function effectively } \\
\text { because the machinery which provides the } \\
\text { "system of operation" is highly dependable } \\
\text { and reliable. A greater focus on "total } \\
\text { reliability management" (TRM) will help } \\
\text { firms to improve their productivity while } \\
\text { reducing costs and increasing } \\
\text { competitiveness. }\end{array}$ & $\begin{array}{l}\text { Madu, Christian N. Reliability and } \\
\text { Quality Interface. International } \\
\text { Journal of Quality \& Reliability } \\
\text { Management, v. 16, n. 7, pp. 691- } \\
698,1999 .\end{array}$ \\
\hline
\end{tabular}

Chart 3: Examples of factors related to reliability.

Source: Prepared by the authors.

The factors related to reliability involve relations with suppliers and the efficiency of equipment. These follow the principles of meeting scheduled delivery times, planning to prevent surprises, controlling the occupation of resources and monitoring production activities (Slack et al., 1997). The expressions related to it found were: reliability, delivery reliability, conformance, trustworthy delivery, on-time delivery, total reliability management, quality measurements and prompt delivery. 


\begin{tabular}{|c|c|c|c|}
\hline FACTOR & $\begin{array}{l}\text { EXPRESSION } \\
\text { FOUND }\end{array}$ & JUSTIFICATION & REFERENCE \\
\hline \multirow{3}{*}{ 峲 } & Knowledge & $\begin{array}{l}\text { Knowledge is considered the basis for } \\
\text { competitive advantage of firms (Conner \& } \\
\text { Prahalad, 1996; Ghemawat, 1986) and its } \\
\text { management is a key to success (Becerra- } \\
\text { Fernandez \& Sabherwal, 2001). }\end{array}$ & $\begin{array}{l}\text { Chilton, Michael A.; Bloodgood, } \\
\text { James M. The Dimensions of Tacit \& } \\
\text { Explicit Knowledge: A Description } \\
\text { and Measure. International Journal of } \\
\text { Knowledge Management, v. 4, n. 2, } \\
\text { June, pp. 75-91, 2008. }\end{array}$ \\
\hline & $\begin{array}{l}\text { Knowledge } \\
\text { Management }\end{array}$ & $\begin{array}{l}\text { Knowledge management combines technical } \\
\text { and organizational initiatives to generate } \\
\text { structured and unstructured knowledge, } \\
\text { contributing to improve efficiency by means } \\
\text { of retaining and reutilizing knowledge. } \\
\text { Organizational efficacy is enhanced by } \\
\text { reusing knowledge to improve decision } \\
\text { making. }\end{array}$ & $\begin{array}{l}\text { Jennex, Murray. What is Knowledge } \\
\text { Management? International Journal } \\
\text { of Knowledge Management. [S.I]. }\end{array}$ \\
\hline & $\begin{array}{l}\text { Knowledge } \\
\text { Management }\end{array}$ & $\begin{array}{l}\text { With the growing importance of knowledge } \\
\text { management, firms are seeing it as a critical } \\
\text { success factor in today's dynamic society } \\
\text { without borders. The provision of knowledge } \\
\text { to the right person at the right time is } \\
\text { fundamental to build and maintain a firm's } \\
\text { competencies. }\end{array}$ & $\begin{array}{l}\text { Alazmi, Mutiran; Zairi, Mohamed. } \\
\text { Knowledge Management Critical } \\
\text { Success Factors. Total Quality } \\
\text { Management, v. 14, n. 2, pp. 199- } \\
\text { 204, 2003. }\end{array}$ \\
\hline
\end{tabular}

Chart 4: Examples of factors related to knowledge.

Source: Prepared by the authors.

Knowledge is an increasingly critical factor for success in the current business environment. The provision of knowledge to the right person at the right time is fundamental to build and maintain a firm's competencies (Alazmi \& Zairi, 2003). Knowledge management combines technical and organizational initiatives to generate structured and unstructured knowledge, contributing to improve efficacy by means of retaining and reusing knowledge. Among the factors found that characterize these principles were: knowledge, understanding of the production system, knowledge management, self-managed learning, learning distribution model, external sources of ideas and knowledge, information management, information and rationalized information flow.

\begin{tabular}{|c|c|c|c|}
\hline FACTOR & $\begin{array}{l}\text { EXPRESSION } \\
\text { FOUND }\end{array}$ & JUSTIFICATION & REFERENCE \\
\hline \multirow{3}{*}{ 氞 } & $\begin{array}{c}\text { Reasonable } \\
\text { Cost }\end{array}$ & $\begin{array}{l}\text { Effective supply chains to create } \\
\text { competitiveness hinge on prompt delivery } \\
\text { of high-quality products and competitive } \\
\text { services, at a reasonable cost and involving } \\
\text { partners in the business (Hewitt, 1994; } \\
\text { Hobbs et al., 1998; Easton, 2002). }\end{array}$ & $\begin{array}{l}\text { Sahay, B.S.; Gupta, Fatinder N.D.; } \\
\text { Mohan, Ramneesh. Managing Supply } \\
\text { Chains for Competitiveness: The Indian } \\
\text { Scenario. Supply Chain Management: } \\
\text { An International Journal., v. 11, n. 1, pp. } \\
\text { 15-24, .2006. }\end{array}$ \\
\hline & Lower Costs & $\begin{array}{l}\text { The focus of good business practices is } \\
\text { reducing wastes and raising competitiveness } \\
\text { through faster response and lower costs. }\end{array}$ & $\begin{array}{l}\text { Schonberger, Richard J. Kanban at the } \\
\text { Nexus - Just in Time Inventory Systems. } \\
\text { Production and Inventory Management } \\
\text { Journal, v. } 43 \text {, n. 2, pp. 1-12, } 2002 \text {. }\end{array}$ \\
\hline & Prices & $\begin{array}{l}\text { Prices and positioning strategies are of } \\
\text { growing strategic importance and a crucial } \\
\text { for long-term competitiveness of small and } \\
\text { medium-sized firms. }\end{array}$ & $\begin{array}{l}\text { Fallon, Grahame; Graham, Stuart; } \\
\text { Willetts, Roger. Pricing and Positioning } \\
\text { for the Single European Currency - The } \\
\text { State of Play among Northampton Small } \\
\text { and Medium-Sized Enterprises. Journal } \\
\text { of Small Business and Enterprise } \\
\text { Development, v.7, n. 2, pp. 171-181, } \\
2000 \text {. }\end{array}$ \\
\hline
\end{tabular}

Chart 5: Examples of factors related to cost.

Source: Prepared by the authors. 
The cost principles are the factors related to the actions taken to modify processes or the product itself, seeking to reduce its final price, by means of making products with few finish details and greater functionality, with simpler and standardized forms and less expensive materials (Slack et al., 1997). The following expressions are included in this logic: low cost, prices, lower costs and reasonable costs.

\begin{tabular}{|c|c|c|c|}
\hline FACTOR & $\begin{array}{c}\text { EXPRESSION } \\
\text { FOUND }\end{array}$ & JUSTIFICATION & REFERENCE \\
\hline \multirow{3}{*}{ 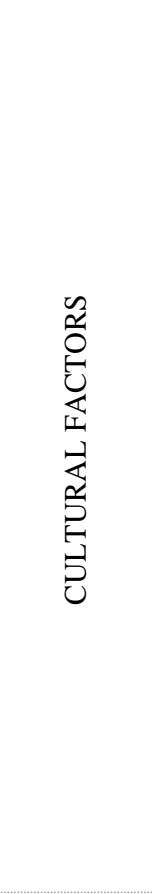 } & $\begin{array}{c}\text { Cultural } \\
\text { Competence }\end{array}$ & $\begin{array}{l}\text { Cultural competence includes all human skills } \\
\text { and organizational factors that promote and } \\
\text { encourage the use of cultural capital in } \\
\text { interaction between people and production. If } \\
\text { the intention is to promote creativity and } \\
\text { innovation in the business, one should consider } \\
\text { cultural interaction as a factor that can lead to } \\
\text { these qualities. }\end{array}$ & $\begin{array}{l}\text { Wilenius, Markku. Cultural } \\
\text { Competence in the Business World: } \\
\text { A Finnish Perspective. Journal of } \\
\text { Business Strategy, v. 27, n. 4, pp. 29- } \\
\text { 43, 2000. }\end{array}$ \\
\hline & $\begin{array}{c}\text { Organizational } \\
\text { Legacy }\end{array}$ & $\begin{array}{l}\text { Porter (1990) identified four attributes that } \\
\text { affect the overall competitiveness of firms: } \\
\text { organizational legacy; demand conditions; } \\
\text { respect and industrial support [industrial respect } \\
\text { and support? Either way it sounds odd.]; and } \\
\text { organizational strategy, structure and } \\
\text { competition. }\end{array}$ & $\begin{array}{l}\text { Hemphill, Thomas A. National } \\
\text { Standards Strategy: Public / Private } \\
\text { Cooperation for Global } \\
\text { Competitiveness. Competitiveness } \\
\text { Review: An International Business } \\
\text { Journal Incorporating Journal of } \\
\text { Global Competitiveness, v. 19, n. 4, } \\
\text { pp. 290-303, 2009. }\end{array}$ \\
\hline & $\begin{array}{l}\text { Organizational } \\
\text { Memory }\end{array}$ & $\begin{array}{l}\text { Stein \& Zwass (1995) and Walsh \& Ungson } \\
\text { (1991) defined organizational memory as the } \\
\text { way the knowledge acquired in the past is } \\
\text { brought to bear on current activities, resulting } \\
\text { in higher or lower levels of organizational } \\
\text { efficiency. The improvement of efficiency can } \\
\text { improve performance and add value to the } \\
\text { organization. }\end{array}$ & $\begin{array}{l}\text { Jennex, Murray E. Impacts from } \\
\text { Using Knowledge: A Longitudinal } \\
\text { Study from a Nuclear Power Plant. } \\
\text { International Journal of Knowledge } \\
\text { Management, v. 4, n. 1, pp. 51-64, } \\
2008 \text {. }\end{array}$ \\
\hline
\end{tabular}

Chart 6: Examples of factors related cultural factors.

Source: Prepared by the authors.

The criteria linked to cultural factors refer to the ideologies, values, laws and daily rituals found in an organization. It is important to understand the different forms of organizational culture and consider them in making decisions. According to Santos (1998), culture is significantly associated with organizational performance, and firms with strong cultures perform better. Its elements are: culture, organizational culture, cultural factors, organizational legacy, organizational memory, zero paradigm, spirituality and clear management policy. 


\begin{tabular}{|c|c|c|c|}
\hline FACTOR & $\begin{array}{l}\text { EXPRESSION } \\
\text { FOUND }\end{array}$ & JUSTIFICATION & REFERENCE \\
\hline \multirow[b]{3}{*}{ 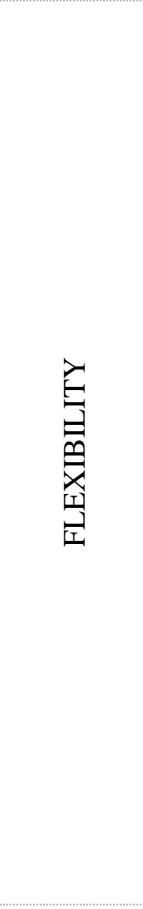 } & Flexibility & $\begin{array}{l}\text { By understanding the importance of flexibility, } \\
\text { strategic processes can enable individuals and } \\
\text { organizations to respond better to the factors } \\
\text { associated with changing opportunities and } \\
\text { demands of customers. }\end{array}$ & $\begin{array}{l}\text { Dwyer, Rocky J. Utilizing Simple } \\
\text { Rules to Enhance Performance } \\
\text { Measurement Competitiveness and } \\
\text { Accountability Growth. Business } \\
\text { Strategy Series Journal, v. 8, n. 1, } \\
\text { pp. 72- 77, 2007. }\end{array}$ \\
\hline & Flexibility & $\begin{array}{l}\text { Six capabilities were identified that organizations } \\
\text { should develop to compete better: price, flexibility, } \\
\text { conformance, performance, speed and delivery } \\
\text { speed. }\end{array}$ & $\begin{array}{l}\text { Ehie, Ike C.; Stough, Stanley. } \\
\text { Cycle Time Reduction through } \\
\text { Various Business Subcycles. } \\
\text { Industrial Management, [S.I.], } \\
\text { May-June, pp. 20-25, 1995. }\end{array}$ \\
\hline & Flexibility & $\begin{array}{l}\text { Six factors that define and measure the working } \\
\text { climate of the organization are: (i) flexibility, } \\
\text { related to how free workers feel to innovate in face } \\
\text { of their bureaucratic obligations; (ii) responsibility } \\
\text { to the organization; (iii) standards, meaning the } \\
\text { level of personal standards people set versus those } \\
\text { set for them; (iv) rewards, not only financial ones, } \\
\text { but anything that helps people feel good about their } \\
\text { contribution, including positive feedback; (v) } \\
\text { clarity, referring to how clearly people know what } \\
\text { is expected of them and how that translates into } \\
\text { action; and (vi) commitment, meaning not just the } \\
\text { professed commitment, but rather the real } \\
\text { commitment people have to the organization. }\end{array}$ & $\begin{array}{l}\text { Goleman, Daniel. Leadership That } \\
\text { Gets Results. Harvard Business } \\
\text { Review,[S.I], March-April, pp. 78- } \\
\text { 90, 2000. }\end{array}$ \\
\hline
\end{tabular}

Chart 7: Examples of factors related to flexibility.

Source: Prepared by the authors.

The constant and sudden changes in the organizational setting require flexibility for better adaptation. Flexibility, also considered as a group of factors, aims to develop the capability for fast response to environmental changes (Slack et al., 1997).

\begin{tabular}{|c|c|c|c|}
\hline FACTOR & $\begin{array}{c}\text { EXPRESSION } \\
\text { FOUND }\end{array}$ & JUSTIFICATION & REFERENCE \\
\hline \multirow{3}{*}{ 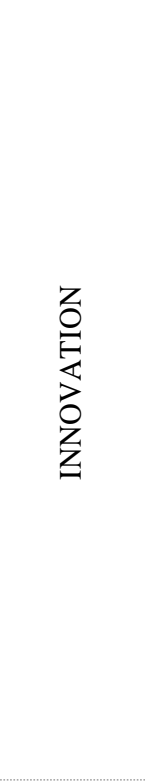 } & Innovation & $\begin{array}{l}\text { To face the challenge of competitiveness it } \\
\text { is necessary to act based on innovation and } \\
\text { knowledge. }\end{array}$ & $\begin{array}{l}\text { Huber, Bernd; Sweeney, Edward. } \\
\text { The Need for Wider Supply Chain } \\
\text { Management Adoption: Empirical } \\
\text { Results from Ireland. Supply Chain } \\
\text { Management: An International } \\
\text { Journal, v. 12, pp. 245-248, } 2007 \text {. }\end{array}$ \\
\hline & Innovation & $\begin{array}{l}\text { For firms to improve their competitiveness } \\
\text { regarding product conception, quality and } \\
\text { prompt delivery, it is necessary to innovate } \\
\text { to produce with maximum efficiency } \\
\text { (Sahay, 2000; Zylbersztajn et al., 2003). }\end{array}$ & 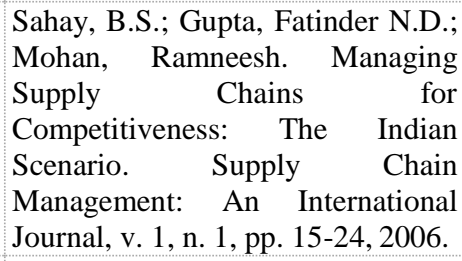 \\
\hline & $\begin{array}{l}\text { Innovation and } \\
\text { Development of } \\
\text { New Products }\end{array}$ & $\begin{array}{l}\text { Innovation and the rapid development of } \\
\text { new products are crucial for companies to } \\
\text { obtain competitive advantage in a global } \\
\text { market. To sustain their competitiveness in } \\
\text { the market, besides price, quality and } \\
\text { speed, they need to develop competencies } \\
\text { to innovate, design and introduce new } \\
\text { products in the market quickly. }\end{array}$ & $\begin{array}{l}\text { Meybodi, Mohammad Z. An } \\
\text { Exploration of The Links between } \\
\text { Just-in-Time Manufacturing and } \\
\text { Simultaneous New Product } \\
\text { Development. Advances in } \\
\text { Competitiveness Research, v.13, n. } \\
\text { 1, pp. 9- 21, 2005. }\end{array}$ \\
\hline
\end{tabular}

Chart 8: Examples of factors related to innovation..

Source: Prepared by the authors. 
There was widespread concern in the texts surveyed about innovation in organizations. This concept is closely tied to changes in the market, described previously, in the global scenario. To remain competitive in the new world order of constant changes, firms need to adopt innovative postures in their productive processes. Therefore, innovation is based on organizational strategies that seek to develop new ways to act, to solve problems and to enhance results. Within this concept, the following expressions were cited: added services, aggressive R\&D (research and development), development of new products, establishment of different operational models, stimulus from involvement in creativity and innovation, innovation, commercial innovation, product innovation, new initiatives, new businesses, new products, production aligned to the market, reorganization of processes, technology of innovation and value added to products.

\begin{tabular}{|c|c|c|c|}
\hline FACTOR & $\begin{array}{l}\text { EXPRESSION } \\
\text { FOUND }\end{array}$ & JUSTIFICATION & REFERENCE \\
\hline \multirow{3}{*}{ 莺 } & $\begin{array}{c}\text { Quality } \\
\text { Certification }\end{array}$ & $\begin{array}{l}\text { Firms that participate in quality } \\
\text { certification programs have higher sales. }\end{array}$ & $\begin{array}{l}\text { Youssef, Mohamed A.; Al-Ghamdi, } \\
\text { Salem M.; Koch, James V.; Dolan, } \\
\text { Tom. Plant Location, ISO } 9000 \\
\text { Certifications and Quality Management } \\
\text { Practices: An Empirical Investigation. } \\
\text { International Journal of Quality \& } \\
\text { Reliability Management, v. 23, n. 8, pp. } \\
\text { 944-963, 2006. }\end{array}$ \\
\hline & $\begin{array}{l}\text { Quality and } \\
\text { Awards for } \\
\text { Excellence }\end{array}$ & $\begin{array}{l}\text { Quality and awards for excellence that } \\
\text { recognize good organizational performance } \\
\text { have become an important driver to } \\
\text { increase competitiveness in the global } \\
\text { economy. }\end{array}$ & $\begin{array}{l}\text { Dutta, Sanjib K. Enhancing } \\
\text { Competitiveness of India Inc.: Creating } \\
\text { Linkages Between Organizational and } \\
\text { National Competitiveness. International } \\
\text { Journal of Social Economics, v. 34, n. } \\
\text { 9, pp. 679-712, 2007. }\end{array}$ \\
\hline & $\begin{array}{l}\text { Quality } \\
\text { Techniques }\end{array}$ & $\begin{array}{l}\text { Quality initiatives, seen as critical for } \\
\text { greater competitiveness, have gained much } \\
\text { attention from management [...]. This has } \\
\text { resulted in widespread adoption of quality } \\
\text { techniques such as quality circles, } \\
\text { teamworking, customer care, total quality } \\
\text { management (TQM) and total productive } \\
\text { maintenance (TPM), etc. }\end{array}$ & $\begin{array}{l}\text { Cooke, Fang Lee. Implementing TPM } \\
\text { in Plant Maintenance: Some } \\
\text { Organizational Barriers. International } \\
\text { Journal of Quality \& Reliability } \\
\text { Management, v. 17, n. 9, pp. 1003- } \\
1016,2000 .\end{array}$ \\
\hline
\end{tabular}

Chart 9: Examples of factors related to quality.

Source: Prepared by the authors.

Quality underpins principles that try to meet customers' expectations regarding products and services and the technical needs of the organization: reduction of errors and the related costs. Its indicators reveal the way organizations obtain standards of quality in their processes and products and meet their customers' expectations, by adopting programs for reduction of errors and imperfections in processes and products. It includes quality of products through continuing improvement. It is linked to factors such as: quality certification, quality circles, quality control, quality management, supplier quality management, quality products, quality management programs, quality techniques and total quality control (TQC). 


\begin{tabular}{|c|c|c|c|}
\hline FACTOR & $\begin{array}{c}\text { EXPRESSION } \\
\text { FOUND }\end{array}$ & JUSTIFICATION & REFERENCE \\
\hline \multirow{3}{*}{ 预 } & $\begin{array}{c}\text { Management of } \\
\text { Time }\end{array}$ & $\begin{array}{l}\text { The way time is managed in such activities as } \\
\text { production, sales and distribution, and new } \\
\text { product development can serve as a major source } \\
\text { of competitive advantage to a firm. }\end{array}$ & $\begin{array}{l}\text { Ehie, Ike C.; Stough, Stanley. } \\
\text { Cycle Time Reduction through } \\
\text { Various Business Subcycles. } \\
\text { Industrial Management, [S.I.], } \\
\text { May-June, pp. 20-25, 1995. }\end{array}$ \\
\hline & $\begin{array}{c}\text { Speed and } \\
\text { Delivery Speed }\end{array}$ & $\begin{array}{l}\text { Six capabilities were identified that organizations } \\
\text { should develop to compete better: price, } \\
\text { flexibility, conformance, performance, speed and } \\
\text { delivery speed. }\end{array}$ & $\begin{array}{l}\text { Ehie, Ike C.; Stough, Stanley. } \\
\text { Cycle Time Reduction through } \\
\text { Various Business Subcycles. } \\
\text { Industrial Management, May- } \\
\text { June, pp. 20-25, 1995. }\end{array}$ \\
\hline & $\begin{array}{l}\text { Fastest } \\
\text { Response }\end{array}$ & $\begin{array}{l}\text { The focus of good business practices is on } \\
\text { reducing wastes and raising competitiveness } \\
\text { through quicker response and lower costs. }\end{array}$ & $\begin{array}{l}\text { Schonberger, Richard J. Kanban } \\
\text { at the Nexus. Production and } \\
\text { Inventory Management Journal, } \\
\text { v. 43, n. 2, pp. 1-12, } 2002 \text {. }\end{array}$ \\
\hline
\end{tabular}

Chart 10: Examples of factors related to speed.

Source: Prepared by the authors.

The principles of speed are based on having a shorter interval between starting the production process and delivery of the product to the customer than competitors can achieve. It means reducing lead time by means of faster flow of information, materials and operations (Slack et al., 1997). The factors tied to this concept found were: delivery, time management, shorter production cycle time, faster response time, fast delivery, reduction of cycle time, faster response and delivery time.

\begin{tabular}{|c|c|c|c|}
\hline FACTOR & $\begin{array}{l}\text { EXPRESSION } \\
\text { FOUND }\end{array}$ & JUSTIFICATION & REFERENCE \\
\hline \multirow{3}{*}{ 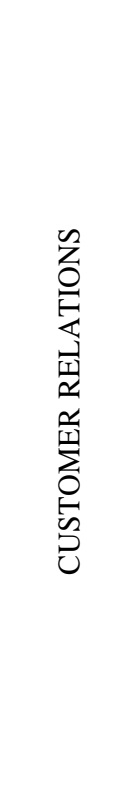 } & $\begin{array}{l}\text { Demand } \\
\text { Conditions }\end{array}$ & $\begin{array}{l}\text { Porter (1990) identified four attributes that affect } \\
\text { the overall competitiveness of firms: } \\
\text { organizational legacy; demand conditions; } \\
\text { industrial respect and support; and organizational } \\
\text { strategy, structure and competition. The demand } \\
\text { conditions are related to the intensity of demand } \\
\text { for the good or service (which winds up } \\
\text { pressuring organizations to improve their } \\
\text { competitiveness). }\end{array}$ & $\begin{array}{l}\text { Hemphill, Thomas A. National } \\
\text { Standards Strategy: Public / Private } \\
\text { Cooperation for Global } \\
\text { Competitiveness. Competitiveness } \\
\text { Review: An International Business } \\
\text { Journal, v. 19, n. 4, pp. 290- 303, } \\
2009 \text {. }\end{array}$ \\
\hline & $\begin{array}{l}\text { Focus on the } \\
\text { Customer }\end{array}$ & $\begin{array}{l}\text { Focus on the customer has been the primary } \\
\text { driver of for implementation of the strategic } \\
\text { alignment focus in organizations. Customers, } \\
\text { whether internal or external, are seen as the } \\
\text { reason for the organization's existence. Satisfying } \\
\text { the needs of customers helps to define the } \\
\text { structure, processes, products and values that an } \\
\text { organization needs to create and foster to be } \\
\text { successful. }\end{array}$ & $\begin{array}{l}\text { Andolsen, Alan. Does Your RIM } \\
\text { Program Need a Strategic } \\
\text { Alignment? The Information } \\
\text { Management Journal, v. 41, n. 4, pp. } \\
\text { 35- 40, 2007. }\end{array}$ \\
\hline & $\begin{array}{l}\text { Production } \\
\text { Aligned with } \\
\text { the Market }\end{array}$ & $\begin{array}{l}\text { Most companies agree that the conditions } \\
\text { necessary for prosperity are to have production } \\
\text { aligned to the needs of the market and conformity } \\
\text { with mega-trends. }\end{array}$ & $\begin{array}{l}\text { Yamashina, Hajime. Japanese } \\
\text { Manufacturing Strategy: Competing } \\
\text { with Tigers. Business Strategy } \\
\text { Review, v. 7, n. 2, pp. 23- 36, } 1996 .\end{array}$ \\
\hline
\end{tabular}

Chart 11: Examples of factors related customer relations.

Source: Prepared by the authors.

Organizational principles aimed at knowing and satisfying customers' needs and expectations and establishing customer loyalty involve customer relations. Their factors are related to the importance of these relations and the need to meet customers' needs and 
expectations. The associated expressions found were: demand conditions, focus on the customer, customer participation, products aligned with the market, public relations and relationships with customers.

\begin{tabular}{|c|c|c|c|}
\hline FACTOR & $\begin{array}{c}\text { EXPRESSION } \\
\text { FOUND }\end{array}$ & JUSTIFICATION & REFERENCE \\
\hline \multirow{3}{*}{ 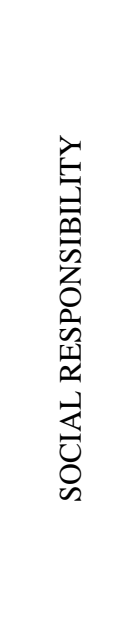 } & $\begin{array}{l}\text { Environmental } \\
\text { Demands }\end{array}$ & $\begin{array}{l}\text { Instead of seeing environmental requirements as } \\
\text { a threat, firms should take the opportunity to } \\
\text { improve their environmental performance, since } \\
\text { customers view this as an important attribute at } \\
\text { the time of making buying decisions. }\end{array}$ & $\begin{array}{l}\text { Greenan, Kate; Humphreys, Paul; McIvor, } \\
\text { Ronan. The Green Initiative: Improving } \\
\text { Quality and Competitiveness for Europeans } \\
\text { SMEs. European Business Review, v. } 97 \text {, } \\
\text { n. 5, pp. 208-214, } 1997 \text {. }\end{array}$ \\
\hline & $\begin{array}{c}\text { Corporate } \\
\text { Social } \\
\text { Responsibility }\end{array}$ & $\begin{array}{l}\text { In a competitive atmosphere, it is important to } \\
\text { use the firm's resources in a proper manner and } \\
\text { for a worthy cause. The real challenge is to } \\
\text { design the firm's corporate social responsibility } \\
\text { strategy in such a way that it helps address a } \\
\text { social issue and also provides the firm with } \\
\text { business benefits. }\end{array}$ & $\begin{array}{l}\text { Bhattacharyya, Som Sekhar; } \\
\text { Arunditya; Arora, Ashok } \\
\text { Chaturvedi, Abha. A Toolkit for Designing } \\
\text { Firm Level Strategic Corporate } \\
\text { Responsibility (CSR) Initiatives. Social } \\
\text { Responsibility Journal, v. 4, n. 3, pp. 265- } \\
\text { 282, 2008. }\end{array}$ \\
\hline & $\begin{array}{c}\text { Clean } \\
\text { Technologies }\end{array}$ & $\begin{array}{l}\text { The use of clean Technologies has spread social } \\
\text { and economic effects that include substantial } \\
\text { increases in productivity and competitiveness, } \\
\text { besides the advantages of environmental quality. }\end{array}$ & $\begin{array}{l}\text { Daniels, Peter L. Technology Revolutions } \\
\text { and Social Development: Prospects for a } \\
\text { Green Thecnoeonomic Paradigm in Lower } \\
\text { Income Countries. International Journal of } \\
\text { Social Economics, v. 32, n. 5, pp.454-482, } \\
2005 \text {. }\end{array}$ \\
\hline
\end{tabular}

Chart 12: Examples of factors related to social responsibility.

Source: Prepared by the authors.

The concern for social responsibility in productive processes has been gaining emphasis in articles that examine ways to promote competitiveness. The adoption of social responsibility measures can improve the performance of manufacturing processes and productivity, by means of more rational use of resources, and can also strengthen the image of firms in the market. In this sense, we found expression such as: environmental demands, waste management, green supply chain management, environmental management, green initiatives, social responsibility and clean technologies.

\begin{tabular}{|c|c|c|c|}
\hline FACTOR & $\begin{array}{l}\text { EXPRESSION } \\
\text { FOUND }\end{array}$ & JUSTIFICATION & REFERENCE \\
\hline \multirow{3}{*}{ 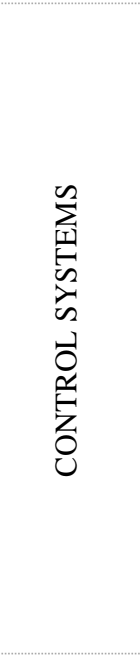 } & $\begin{array}{l}\text { Performance } \\
\text { Evaluation }\end{array}$ & $\begin{array}{l}\text { The assessment of performance is vital for any organization } \\
\text { that aspires to achieve high levels of efficiency and } \\
\text { competitiveness. In its various forms, performance } \\
\text { evaluation really represents the benchmark values that tell } \\
\text { people how they have acted and thus motivates them to meet } \\
\text { higher objectives. }\end{array}$ & $\begin{array}{l}\text { Zairi, Mohamed. Benchmarking: } \\
\text { The Best Tool for Measuring } \\
\text { Competitiveness. Benchmarking } \\
\text { for Quality Management \& } \\
\text { Technology, v. 1, n. 1, pp. } 11-24 \text {, } \\
1994 .\end{array}$ \\
\hline & $\begin{array}{l}\text { Coordination, } \\
\text { Traceability, } \\
\text { Standardizatio } \\
\mathrm{n} \text { and } \\
\text { Certification }\end{array}$ & $\begin{array}{l}\text { True competitive advantage is related to the dynamic } \\
\text { capabilities created in processes. The need to create } \\
\text { coordination mechanisms to meet demands in terms of } \\
\text { quality, traceability, standardization and certification, which } \\
\text { are the key elements to build the dynamic capabilities for } \\
\text { insertion in the global market. }\end{array}$ & $\begin{array}{l}\text { Zilbersztajn, Decio; Machado } \\
\text { Filho, Cláudio A. Pinheiro. } \\
\text { Competitiveness of Meat Agri- } \\
\text { Food Chain in Brazil. Supply } \\
\text { Chain Management: An } \\
\text { International Journal, v. 8, n. 2, } \\
\text { pp. 155-165, 2003. }\end{array}$ \\
\hline & Rules & $\begin{array}{l}\text { The incorporation of simple rules to guide strategic } \\
\text { processes increases competitiveness and growth, thus } \\
\text { enhancing the performance measurement and accountability } \\
\text { of organizations. }\end{array}$ & $\begin{array}{l}\text { Dwyer, Rocky J. Utilizing Simple } \\
\text { Rules to Enhance Performance } \\
\text { Measurement Competitiveness } \\
\text { and Accountability Growth. } \\
\text { Business Strategy Series Journal, } \\
\text { v. 8, n.1, pp. 72- 77, 2007. }\end{array}$ \\
\hline
\end{tabular}

Chart 13: Examples of factors related to control systems.

Source: Prepared by the authors. 
Another group of factors found were based on criteria such as: performance evaluation, auditing, balanced scorecard, certification, conformity, control, coordination, discipline, establishment of verification systems, standardization, execution of strategies, execution of plans, feedback, maintenance, maintenance and security, total productivity maintenance, performance measurements, standardized patterns, traceability, rules and Kanban control systems. These all involve control and standardization of operations and seek to establish mechanisms to assure that the final product meets the specifications determined by the company, by means of control systems.

\begin{tabular}{|c|c|c|c|}
\hline FACTOR & $\begin{array}{l}\text { EXPRESSION } \\
\text { FOUND }\end{array}$ & JUSTIFICATION & REFERENCE \\
\hline \multirow{3}{*}{ 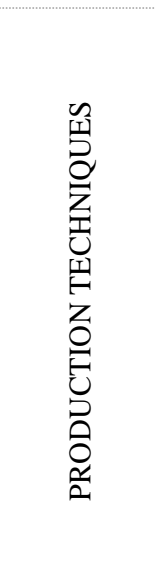 } & $\begin{array}{c}\text { Project } \\
\text { Management }\end{array}$ & $\begin{array}{l}\text { Project management is a powerful tool that } \\
\text { can be used throughout the organization to } \\
\text { increase productivity and assure return on } \\
\text { investment. }\end{array}$ & $\begin{array}{l}\text { Larosse, Michelle. Build the Business } \\
\text { with Powerful Project Management. } \\
\text { Industrial Management, v. 47, n. 1, } \\
\text { Jan.-Feb., pp. 22-26, } 2005 \text {. }\end{array}$ \\
\hline & $\begin{array}{l}\text { Holistic } \\
\text { Management } \\
\text { and Best } \\
\text { Practices }\end{array}$ & $\begin{array}{l}\text { Successful companies maintain their } \\
\text { competitive advantage over rivals by } \\
\text { holistic management of the best practices. }\end{array}$ & $\begin{array}{l}\text { Appleby, Alex; Mitchell, Ed. } \\
\text { Something for nothing? A } \\
\text { Comparison of Practice and } \\
\text { Performance in Vulnerable and } \\
\text { Promising Companies. Integrated } \\
\text { Manufacturing Systems, v. 13, n. 3, } \\
\text { pp. 150-157, 2002. }\end{array}$ \\
\hline & Planning & $\begin{array}{l}\text { Planning continues being a natural way to } \\
\text { guide systems and reach coordinated } \\
\text { objectives and reduce risks. }\end{array}$ & $\begin{array}{l}\text { Jablonowski, Mark. The Bigger } \\
\text { Picture: Recognizing Risk } \\
\text { Management's Social Responsibility. } \\
\text { Risk Management, [S.I.], Sept., pp. } \\
\text { 50-54, 2009. }\end{array}$ \\
\hline
\end{tabular}

Chart 14: Examples of factors related to production techniques.

Source: Prepared by the authors.

Various factors found can be considered most closely linked to production techniques. These are elements related, for example, to the adoption of practices to reduce waste and use resources more efficiently, the search for continuous improvements and adding value to the production steps. The factors that can be considered in this group are: project management, total quality management, planning, holistic management and best practices, benchmarking, efficient resource use, organizational strategy, dimensioning of productive capacity, industrial policy, lean production, management excellence, lean management, continuous change, integration of production techniques (just-in-time, total quality management and supply chain management), improved productivity, Kaizen, Kanban, total productive management, continuous improvement, reduction of waste, improved operations, product design, production programming and rationalization of materials flow. 


\begin{tabular}{|c|c|c|c|}
\hline FACTOR & $\begin{array}{c}\text { EXPRESSIO } \\
\text { N FOUND }\end{array}$ & JUSTIFICATION & REFERENCE \\
\hline \multirow{3}{*}{ 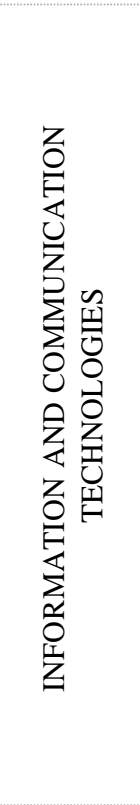 } & $\begin{array}{l}\text { Information } \\
\text { Management }\end{array}$ & $\begin{array}{l}\text { Besides preventing and controlling risks, effective } \\
\text { management of records and information can lead to } \\
\text { improved performance. Records and information risk } \\
\text { management initiatives help to identify and capitalize on } \\
\text { opportunities to manage information strategically and } \\
\text { help to minimize risks and losses. }\end{array}$ & $\begin{array}{l}\text { Lemieux, Victoria L. Two } \\
\text { Approaches to Managing } \\
\text { Information } \quad \text { Risks. The } \\
\text { Information } \\
\text { Journal, [S.I.], Sept.-Oct., pp. } \\
\text { 56-62, 2004. }\end{array}$ \\
\hline & $\begin{array}{l}\text { Information } \\
\text { Systems }\end{array}$ & $\begin{array}{l}\text { Information systems are fundamental parts of global } \\
\text { strategies because large amounts of data can be } \\
\text { transmitted over long distance virtually instantaneously. } \\
\text { Therefore, managers located on different continents can } \\
\text { share the same data and applications easily and quickly. } \\
\text { These trends represent new opportunities for managers } \\
\text { to redesign their organizations and their relations with } \\
\text { commercial partners. }\end{array}$ & $\begin{array}{l}\text { Holland, Christopher et al. The } \\
\text { Evolution of a Global Cash } \\
\text { Management System. Sloan } \\
\text { Management Review, v. 36, } \\
\text { n.1, March, pp.37-47, 1994. }\end{array}$ \\
\hline & $\begin{array}{l}\text { Information } \\
\text { and } \\
\text { Communicati } \\
\text { on } \\
\text { Technologies }\end{array}$ & $\begin{array}{l}\text { Investment in information and communication } \\
\text { Technologies are key factors not only for reasons of } \\
\text { efficiency, but also for strategic reasons. Small } \\
\text { businesses can use these Technologies to improve } \\
\text { relations with their partners, thus expanding their } \\
\text { influence on these partners' strategies and offering more } \\
\text { efficient and effective ways of working. }\end{array}$ & $\begin{array}{l}\text { Onajaefe, Darlington; Leaning, } \\
\text { Marcus. The Importance of } \\
\text { Partnerships: The Relationships } \\
\text { Between Small Business, ICT } \\
\text { and Local Communities. } \\
\text { Informing Science and } \\
\text { Information Technology, v. 4, } \\
\text { [S.I.], pp. 725-737, 2007. }\end{array}$ \\
\hline
\end{tabular}

Chart 15: Examples of factors related to information and communication technologies.

Source: Prepared by the authors.

In the new scenario faced by organizations, information and communication technologies (ITCs) are playing an increasingly important role in determining their performance. This scenario is characterized by the disappearance of borders between competing firms, because distance is no longer an entry barrier to new rivals. This is due in large part to the advances from the use of information and communication technologies, which allow a considerable reduction in transaction costs between economic agents. It was possible in this respect to note in the texts studied terms like: information systems, information management, information and communication technologies and open communication channels.

The authors of these articles believe that such factors are essential in the search for competitiveness. These observations are important and should be heeded so that organizations can perform and compete better, among other aspects by controlling objectives better. These factors not only permit determining strategic paths to take, they also help set priorities to achieve better performance and competitiveness.

\section{FINAL CONSIDERATIONS}

The objective of this article was to identify in the business literature the elements that lead to competitive firms. The subject of what priorities and policies serve firms best to develop and sustain competitive advantage over the long term is addressed by a huge body of literature. 
The data were obtained from periodicals available from sources listed at the CAPES portal in the period from 2000 to 2009, through a keyword search to identify those covering themes related to competitiveness, productivity, efficiency and performance. We found 15 groups of organizational competitiveness factors: strategic alliances, human capital, reliability, knowledge, cost, cultural factors, flexibility, innovation, quality, speed, customer relations, social responsibility, control systems, production techniques and information and communication technologies.

These factors, considering the specificities of each firm and its sector, can constitute the base for developing organizational strategies and formulating management tools to enable identification of actions to improve performance.

The results found are coherent with those of other authors recognized in the field (Slack et al., 1997; Davis, 2001; Scopinho, 2000; Buiar, 1999; Stevenson, 2001; Buffa, 1972; Machado da Silva, 2002).

We hope the results presented here will serve as the starting point for further research in the area. More comprehensive knowledge of the aspects examined here can provide important guidance to managers on new ways of management, enabling them to face the dynamic changes of the current market.

\section{REFERENCES}

ALAZMI, Mutiran; ZAIRI, Mohamed. Knowledge Management Critical Success Factors. Total Quality Management, v. 14, n. 2, p. 199-204, 2003.

ANSOFF, H. I. Corporate strategy. Harmondsworth: Penguin, 1965.

BANDEIRA, Anselmo Alves. Avaliação de desempenho: uma abordagem estratégica em busca da produtividade. Rio de Janeiro: Qualitymark, 2007.

BARDIN, Laurence. Análise de conteúdo. Lisboa: Edições 70, 2004.

BUFFA, Elwood S. Administração da produção. Rio de janeiro: Livros Técnicos e Científicos, 1972.

BUIAR, Denise Rauta. Flexibilidade Como Vantagem Competitiva no Novo Paradigma Tecnológico. In: Encontro Nacional de Engenharia de Engenharia de Produção - 1998, 1998, Niterói- RJ. ENEGEP-1998, 1998. CD.

CASTRO, Mario; SANTOS, Fernando César Almada; SILVA, Eliciane Maria. A Relação entre Prioridades Competitivas e Indicadores de Desempenho: Survey em Empresas 
Moveleiras. Simpósio de Administração da Produção, Logística e Operações Internacionais, 11. 2008. São Paulo.

DAVIS, Mark. Fundamentos da administração da produção. Porto Alegre: Bookman, 2001.

LEMOS, A.D.; NASCIMENTO, L. F.. A Produção Mais Limpa como Geradora De Inovação e Competitividade. Revista de Administração de Empresas, v.3, n. 1, p. 23 -46, 1999.

MACHADO-DA-SILVA, Clóvis Lima; BARBOSA, S. L.. Estratégia, Fatores de Competitividade e Contexto de Referência das Organizações: Uma Análise Arquetípica.

Revista da Administração Contemporânea, v. 6, n. 3, p. 7-32, 2002.

PORTER, Michael. From Competitive Advantage to Corporate Strategy. In: GOOLD, M.; LUCHS, K. S. Managing the Multibusiness Company- Strategic Issues for Diversified Groups. Nova York: British Library, 2001.

RICHARDSON, R. et al. Pesquisa social: métodos e técnicas. São Paulo: Atlas, 1999.

RUSSO, G.; MACEDO-SOARES, T.; VILLAS, M. Importância da hierarquização das revistas científicas: resultados de uma investigação empírica no Brasil e proposta de um método de pesquisa bibliográfica. In: Anais... 30 . Encontro da ANPAD, Salvador, 2006.

SANTOS, Neusa Maria Bastos Fernandes dos. Cultura e desempenho organizacional: um estudo empírico em empresas brasileiras do setor têxtil. Revista de Administração Contemporânea, v. 2, n. 1, abr., 1998. [S.I.].

SANTOS, Fernando César Almada; PIRES, Silvio Roberto Ignacio; GONÇALVES, Marilson Alves. Prioridades Competitivas na Administração Estratégica da Manufatura: Estudos de Casos. Revista de Administração de Empresas, v. 39, n. 4, p. 78-84.1999.

SCOPINHO, R. A.. Qualidade Total e Saúde e Segurança no Trabalho: O Caso do Setor Sucroalcooleiro da Região de Ribeirão Preto-SP. In: II Congresso Brasileiro de Ciências Sociais em Saúde, 1999, São Paulo. II Congresso Brasileiro de Ciências Sociais em Saúde. São Paulo-SP: ABRASCO - Associação Brasileira de Saúde Coletiva, 1999. v. 1, p. $60-61$.

SILVA, S. L.. Informação e competitividade: a contextualização da gestão do conhecimento nos processos organizacionais. Ciência da Informação [online], v. 31, n. 2, p. 142-151, 2002. Disponível em: http://www.scielo.br/pdf/ci/v31n2/12917.pdf . Acesso em: 21 de mar. 2010.

SKINNER, W. Manufacturing: the Missing Link in Corporate Strategy. Harvard Business Review, v.47, n. 3, p. 136-145, 1969.

SLACK, N. et al. Administração da produção. São Paulo: Atlas, 1997.

STEVENSON, W. J. Administração das operações de produção. Rio de Janeiro: LTC, 2001. 